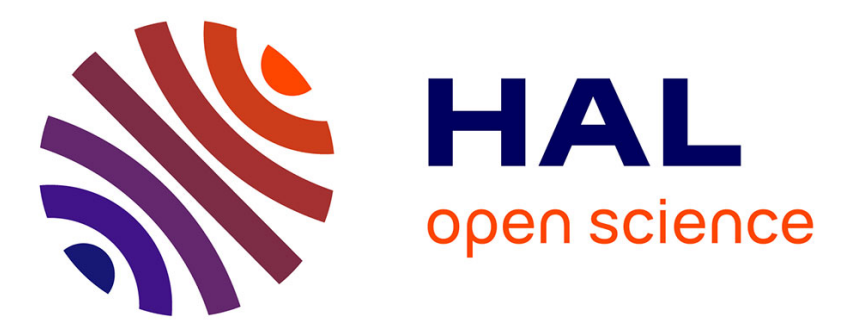

\title{
THE STRUCTURE OF AMORPHOUS ALLOYS SYNTHESIZED BY MECHANICAL ALLOYING-NON GLASS FORMING SYSTEMS
}

\author{
C. Koch, M. Kim
}

\section{- To cite this version:}

C. Koch, M. Kim. THE STRUCTURE OF AMORPHOUS ALLOYS SYNTHESIZED BY MECHANICAL ALLOYING-NON GLASS FORMING SYSTEMS. Journal de Physique Colloques, 1985, 46 (C8), pp.C8-573-C8-577. 10.1051/jphyscol:1985891 . jpa-00225244

HAL Id: jpa-00225244

https://hal.science/jpa-00225244

Submitted on 1 Jan 1985

HAL is a multi-disciplinary open access archive for the deposit and dissemination of scientific research documents, whether they are published or not. The documents may come from teaching and research institutions in France or abroad, or from public or private research centers.
L'archive ouverte pluridisciplinaire HAL, est destinée au dépôt et à la diffusion de documents scientifiques de niveau recherche, publiés ou non, émanant des établissements d'enseignement et de recherche français ou étrangers, des laboratoires publics ou privés. 
JOURNAL DE PHYSIQUE

Colloque C8, supplément au $n^{\circ} 12$, Tome 46, décembre 1985

page $\mathrm{C} 8-573$

THE STRUCTURE OF AMORPHOUS ALLOYS SYNTHESIZED BY MECHANICAL ALLOYINGNON GLASS FORMING SYSTEMS

C.C. Koch and M.S. Kim

North Carolina State University, Box 7907, Raleigh, NC 27695-7907, U.S.A.

Résumé - Des résultats préliminaires, décrivant l'amorphisation de $\mathrm{Nb}-\mathrm{Sn}$ et $\mathrm{Nb}-\mathrm{Ge}$ par mise en solution mécanique des composants, sont prësentés. La calorimétrie différentielle à balayage permet de caractériser l'état amorphe par 7'observation des pics de cristallisation et, associée aux mesures de diffraction, suggère une évolution importante de la structure au cours du recuit thermique.

Abstract - Preliminary resuTts are reported of the amorphization of $\mathrm{Nb}-\mathrm{Sn}$ and $\mathrm{Nb}-\mathrm{Ge}$ alloys by mechanical al loying of the elemental powders. Nb-25 at.\% Sn, $\mathrm{Nb}-25$ at.\% Ge, and $\mathrm{Nb}-27$ at.\% Ge alloys were made amorphous. Differential scanning calorimetry (DSC) indicated a crystallization peak at $995 \mathrm{~K}$ for $\mathrm{Nb}-25$ at.\% $\mathrm{Sn}$ but $>1000 \mathrm{~K}$ for the $\mathrm{Nb}-\mathrm{Ge}$ amorphous alloys. A large endothermic DSC peak and the diffraction patterns of the as-mechanically alloyed vs. heated $\mathrm{Nb}-27$ at.\% Ge amorphous alloy suggest a large change in the structure of the amorphous phase.

\section{I - INTRODUCTION}

Amorphous alloys have been prepared by a variety of methods. These methods may be classified according to the nature of the precursor to the amorphous structure e.g. synthesis from the liquid state, vapor state, or aqueous solution. Synthesis of the amorphous structure from the crystalline solid has been given increasing attention in recent years. Techniques in this regard include ion implantation $/ 1 /$, ion bombardment $/ 2 /$, neutron-irradiation $/ 3 /$, ion mixing of metallic bilayers $/ 4 /$, and solid-state interdiffusion $/ 5 /$. Koch et al $/ 6 /$ have demonstrated that mechanical alloying of elemental $\mathrm{Ni}$ and $\mathrm{Nb}$ powders by high energy ball milling for extended times leads to the formation of an amorphous alloy powder. Mechanical alloying (MA) is a high-energy ball milling technique for producing composite metal powders with controlled microstructures by the repeated cold welding and fracture of powder particles. If MA is continued to the point where the starting powders are mixed to dimensions of a few atomic spacings, then an "alloy" of the elemental powders can be formed. The composition range over which the amorphous structure can be attained has been extended by MA over that produced by rapid solidification in both the $\mathrm{Ni}-\mathrm{Nb}$. system ( $\mathrm{P}$. Y. Lee and $\mathrm{C}$. $\mathrm{C}$. Koch, unpubl ished research, North Carolina State University) and the $\mathrm{Ni}-\mathrm{Ti}$ system (R. B. Schwarz and coworkers, Argonne National Laboratory, private communication).

Both of the above alloy systems are "easy glass formers". That is, the amorphous structure can be produced by "conventional" rapid solidification processing (quench rate $-106 \mathrm{~K} / \mathrm{s}$ ) over fairly wide ranges of composition. While additional studies of such glass forming systems prepared by MA are being conducted in our laboratory we are also studying the feasibility of producing the amorphous structure by MA 
in non glass forming systems. The two systems picked for this study are Nb-Sn and $\mathrm{Nb}-\overline{\mathrm{Ge}}$. Alloys with the compositions $\mathrm{Bb}_{3} \mathrm{Sn}$ and $\mathrm{Nb}_{3} \mathrm{Ge}$ have been made amorphous by vapor quenching methods, e.g. $/ 7 /$. However, no amorphous phases have been produced in these systems by rapid solidification methods at usual quenching rates $\left(10^{6} \mathrm{~K} / \mathrm{s}\right)$ - that is, they are non glass forming.

This paper presents the results of preliminary studies of the feasibility of synthesizing the amorphous structure by $\mathrm{MA}$ of $\mathrm{Nb}-\mathrm{Sn}$ and $\mathrm{Nb}-\mathrm{Ge}$ powders. The stability of the amorphous phases so formed was also examined.

\section{II - EXPERIMENTAL}

The MA was carried out on pure elemental powders of Nb (Alfa Products, $99.8 \%$ - 325 mesh), Sn (Alfa Products, 99.5\%, - 325 mesh), and Ge (Alfa Products, $99.999 \%,-325$ mesh). Mechanical alloying was performed in a Spex Mixer/Mill Model 8000 . Martensitic stainless steel balls (AISI 44,0C), which were $7.9 \mathrm{~mm}$ in diameter, were used in the cylindrical hardened tool steel vial (76 x $57 \mathrm{~mm}$ diameter). The elemental powders were loaded in the vial under air with a ball to powder weight ratio of $6: 1$. In some cases the vial was opened after a given time and a small sample of powder was removed for x-ray diffraction analysis. In other cases MA was continued to a final processing time before the vial was opened. Recently several experiments were conducted with a slit in the vial cap to allow for the insertion of a thermocouple. This provided a continuous source of air (oxygen) to the powders. The oxygen that is certainly incorporated in the MA powder has not yet been analyzed for. However, based on previous results on MA of $\mathrm{Ni} 60 \mathrm{Nb} 40$ in air $/ 6 /$, it is expected that at least 3 wt.\% oxygen may be contained in the present powders. Three conditions were used in terms of the average temperature of the vial during MA. If no attempt were made to remove the heat generated by the kinetic energy of the balls etc., the vial temperature, as measured by either external or internal thermocouples, would reach approximately $65^{\circ} \mathrm{C}$ after extended periods. Forced convection for heat removal with a fan lowered the average temperature to about $35^{\circ} \mathrm{C}$. In order to obtain additional cooling a flow of liquid nitrogen was impinged upon the vial during MA. The average temperature attained was not as reproducible as the above conditions due to difficulties in controlling the liquid nitrogen flow on the rapidly moving vial. Temperatures of $-150 \mathrm{C} \pm 5^{\circ} \mathrm{C}$ were observed.

The structures of the MA powders were followed by $x$-ray diffraction measurements using cylindrical samples (powder uniformly coated on a glass fiber) in a $57.3 \mathrm{~mm}$ diameter Debye-Scherrer camera. The $x$-ray radiation used was CuK $\alpha(\lambda=0.154 \mathrm{~nm})$. Several samples were also examined in a Philips APD 3600-02 automated powder diffractometer.

The powder morphology as a function of MA time was followed by optical and scanning electron microscopy. Microhardness measurements were made on metallographically mounted powders using a Buehter Micromet microhardness tester.

Initial studies of the amorphous phase stability were carried out by heating the amorphous powders in a Perkin-ETmer differential scanning calorimeter (DSC II) at $20 \mathrm{~K} / \mathrm{min}$.

\section{III - RESULTS}

\section{A. Amorphous Phase Formation}

1. Nb-Sn System

The only alloy studied to date in the $\mathrm{Nb}-\mathrm{Sn}$ system is $\mathrm{Nb}-25$ at.\% $\mathrm{Sn}$. It was necessary to cool the vial during MA to prevent excessive cold welding of the $\mathrm{Sn}$ powders to the vial wall and the balls. Because of this experimental inconvenience more compositions have been examined in the $\mathrm{Ab}-\mathrm{Ge}$ system. 
The progress of structural changes during MA was observed in Nb-25 at.\% Sn by x-ray diffraction measurements taken as a function of time of MA. The diffraction patterns changed with MA time in the following manner: first the $\mathrm{Nb}$ and $\mathrm{Sn} 1$ ines broadened; then the $\mathrm{Sn} 1$ ines could not be resolved; the peak position of the (110) $\mathrm{Nb}$ line moved to lower angles and the line width increased; finally, a diffraction pattern typical of the amorphous structure developed. There is an almost 7 inear decrease in (170) peak $2 \theta$ up to about 14 hours of $M A$, (at $-15^{\circ} \mathrm{C}$ ) after which time $2 \theta$ stays constant and the amorphous diffraction pattern develops. Similar results were obtained previously for the $\mathrm{Ni}_{60} \mathrm{Nb}_{40}$ alloy /6/. The changes in $2 \theta$ must reflect the "alloying" stage of the process as the dimensions of the component powders are reduced to the atomic level. After "alloying" is complete the transformation to the amorphous structure occurs.

The time at which the amorphous structure forms varied with temperature as is indicated in Table 1 . The time for attainment of the amorphous phase appears to go through a maximum at $35^{\circ} \mathrm{C}$ and MA at $-15 \pm 5^{\circ} \mathrm{C}$ gives the shortest time. The same temperature dependence has also been observed for amorphization time in the $\mathrm{Nb}-\mathrm{Ge}$ alloys to be discussed below.

Table 1

Amorphization of $\mathrm{Nb}-\mathrm{Sn}, \mathrm{Nb}-\mathrm{Ge}$ Alloys by Mechanical Alloying

\begin{tabular}{|c|c|c|c|}
\hline \multirow[t]{2}{*}{ Alloy Composition } & \multirow[t]{2}{*}{$\begin{array}{l}\text { Phase Formed } \\
\text { by M.A. }\end{array}$} & \multicolumn{2}{|c|}{$\begin{array}{l}\text { Time for Amorphization } \\
\text { by M.A. (hours) }\end{array}$} \\
\hline & & Time & Ave. Temp. \\
\hline $\mathrm{Nb}-25$ at. $\% \mathrm{Sn}$ & Amorphous & $\begin{array}{l}18.5 \\
27 \\
23\end{array}$ & $\begin{array}{l}-15{ }^{ \pm} \pm 5^{\circ} \mathrm{C} \\
35^{\circ} \mathrm{C} \\
65^{\circ} \mathrm{C}\end{array}$ \\
\hline $\mathrm{Nb}-25$ at. $\% \mathrm{Ge}$ & Amorphous & $\begin{array}{l}10 \\
11\end{array}$ & $\begin{array}{l}-15 \\
65^{\circ} \mathrm{C}\end{array}$ \\
\hline $\mathrm{Nb}-27$ at.\% Ge & Amorphous & $\begin{array}{r}7 \\
18 \\
10\end{array}$ & $\begin{array}{l}-15 \pm 5^{\circ} \mathrm{C} \\
35^{\circ} \mathrm{C} \\
65^{\circ} \mathrm{C}\end{array}$ \\
\hline $\mathrm{Nb}-38$ at. $\% \mathrm{Ge}$ & $\mathrm{Nb}_{5} \mathrm{Ge}_{3}$ & & \\
\hline $\mathrm{Nb}-59$ at. $\% \mathrm{Ge}$ & $\mathrm{NbGe}_{2}$ & & \\
\hline $\mathrm{Nb}-67$ at.\% Ge & $\mathrm{NbGe}_{2}$ & & \\
\hline
\end{tabular}

\section{2. $\mathrm{Nb}-\mathrm{Ge}$ System}

Due to the brittle mechanical behavior of Ge, excessive cold welding was not a problem in $\mathrm{MA}$ of the $\mathrm{Nb}-\mathrm{Ge}$ alloys. In all cases the starting material consisted of the elemental $\mathrm{Nb}$ and Ge powder. Of the five compositions studied to date, only the 25 at.\% Ge and 27 at.\% Ge alloys could be made amorphous by MA (see Table 1). The 38, 59, and 67 at.\% Ge compositions formed the structures, 1 isted in Table 1, which are consistent with the phases found in the equilibrium diagram at those compositions.

\section{B. Stability of the Amorphous Structure}

Preliminary measurements of the stability of the amorphous phases in the Nb-25 at.\% $\mathrm{Sn}, \mathrm{Nb}-25$ at.\% Ge, and $\mathrm{Nb}-27$ at.\% Ge alloys were made by differential scanning calorimetry (DSC).

On heating in the DSC at $20 \mathrm{~K} / \mathrm{min}$ the $\mathrm{Nb}-25$ at.\% Sn sample exhibited a large endothermic peak which started at $540 \mathrm{~K}$, peaked at $660 \mathrm{~K}$, then merged into the 
exothermic crystallization curve at about $920 \mathrm{~K}$. The exothermic peak occured at $995 \mathrm{~K}$, amost at the temperature limit of the DSC II. X-ray diffraction of the powder after the DSC run indicated the presence of the $\mathrm{Nb}_{6} \mathrm{Sn}_{5}$ and $\mathrm{NbSn}_{2}$ phases.

Similar DSC experiments on the Nb-25 at.\% Ge and Nb-27 at.\% Ge amorphous powders also revealed broad endothermic peaks which started at about $600 \mathrm{~K}$ and peaked at about $780 \mathrm{~K}$ (25 at.\% Ge) or about $860 \mathrm{~K}(27$ at.\% Ge). While the DSC traces of both these ailoys became exothermic at temperatures above $900 \mathrm{~K}$ ( $920 \mathrm{~K}$ for 25 at.\% $\mathrm{Ge}, 960 \mathrm{~K}$ for 27 at.\% Ge) no exothermic peak could be obtained up to the temperature limit of the DSC $(1000 \mathrm{~K})$.

X-ray diffraction patterns for the amorphous $\mathrm{Nb}-27$ at.\% Ge powder in the as-MA condition and after heating in the DSC at $20 \mathrm{~K} / \mathrm{min}$ to $1000 \mathrm{~K}$, (and subsequent cooling to room temperature) are illustrated in Figures $\mathrm{Ib}$ and $\mathrm{la}$ respectively. Figure 1b shows a diffraction pattern which is typical of those we have observed for "amorphous" MA powders. The intensities of the first and second peaks are considerably lower than usually observed for liquid-quenched amorphous alloys. After the temperature excursion to $1000 \mathrm{~K}$ in the DSC the diffraction pattern (Figure $1 \mathrm{a}$ ) more closely resembles that for a liquid-quenched alloy. That is, the intensities of both the first and second peaks have increased and the second peak shows the characteristic splitting. Very small Bragg peaks can be seen above the amorphous pattern as evidence of the start of crystallization, which is consistent with the beginnings of the exothermic reaction observed in the DSC experiment.

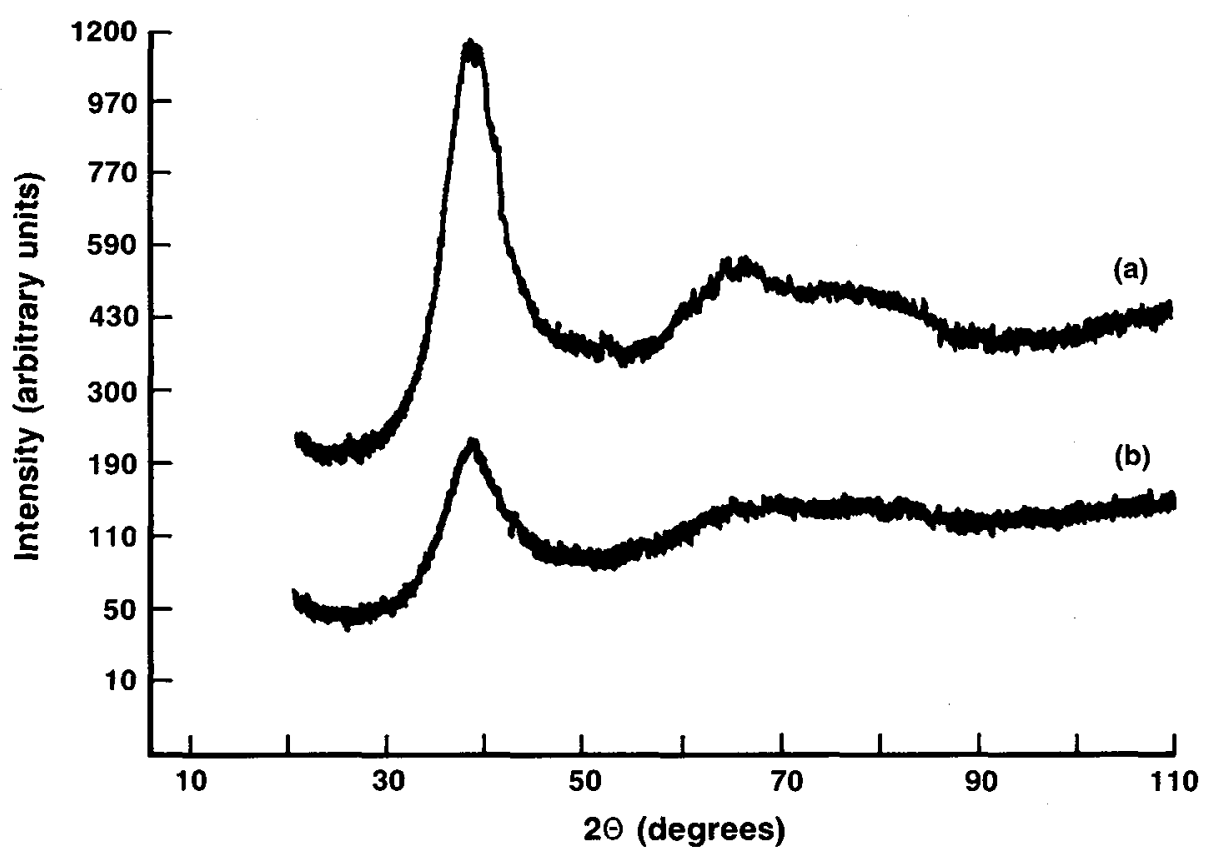

Figure 1 (a) Diffraction pattern of $\mathrm{Nb}-27$ at.\% Ge amorphous alloy produced by MA heated to $1000 \mathrm{~K}$ at $20 \mathrm{~K} / \mathrm{min}$ in DSC.

(b) Diffraction pattern of $\mathrm{Nb}-27$ at.\% Ge amorphous alloy as-mechanically alloyed. 


\section{DISCUSSION}

While the preliminary results presented above are not extensive enough to draw general conclusions regarding the amorphization tendency by $\mathrm{MA}$ for the $\mathrm{Nb}-\mathrm{Sn}$ and $\mathrm{Nb}-$ Ge systems, some comments on possible mechanisms are in order. Crystalline solids have been amorphized by ion, neutron, and electron irradiation (e.g. $/ 2 /, / 3 /, / 8 /$ respectively). A mechanism first proposed by Swanson et al $/ 3 /$ has been used to explain amorphization by irradiation of crystalline solids. It involves the concept of a critical defect concentration introduced by irradiation such that spontaneous transformation to the amorphous state will occur when the free energy of the crystalline phase $\left(G_{C}\right)$ plus the free energy increase due to defects produced by irradiation $\left(G_{D}\right)$ is greater than the free energy of the amorphous phase $\left(G_{A}\right)$ : that is, $G_{C}+G_{D}$ $>G_{A}$. A critical defect density may be the controlling mechanism for amorphization by mechanical alloying.

The mechanism presented for amorphization by solid state diffusion involves systems with large negative heats of mixing in the liquid (or amorphous) alloys and anomalously fast diffusion $/ 5 /$. If solid state diffusion were the controlling mechanism in the amorphization of $\mathrm{Nb}-\mathrm{Sn}$ and $\mathrm{Nb}-\mathrm{Ge}$ alloys by MA then it might be expected that the time of MA for amorphization would decrease with increasing temperature. Our preliminary results do not indicate such a trend. Clearly more work is needed to determine the mechanism(s) responsible for amorphization by MA as a function of composition.

The above preliminary results on the occurrence and structure of the MA amorphous $\mathrm{Nb}-\mathrm{Sn}$ and $\mathrm{Nb}-\mathrm{Ge}$ alloys have provided several important questions to be resolved by further research.

\section{ACKNOWLEDGEMENTS}

The authors wish to thank C. G. Mckamey and O. B. Cavin of Oak Ridge National Laboratory for the DSC and $x$-ray diffractometer measurements, respectively. The research was sponsored by the U. S. National Science Foundation under NSF Grant No. DMR8318561 .

\section{REFERENCES}

/1/ Grant, W. A., J. Vac. Sci. Technol. 15 (1978) 1644.

12/ Brimhal], J. L., Kissinger, H. E., and Charlot, L. A., Radiation Effects 77 (1983) 237.

13/ Swanson, M. L., Parsons, J. R., and Hoelke, C. W., Radiation Effects $\underline{9}$ (197) 249.

14/ Cheng, Y-T., Van Rossum, M., Nicolet, M-A., and Johnson, W. L., App]. Phys. Lett. 45 (1984) 185.

/5/ Schwarz, R. B., and Johnson, W. L., Phys. Rev. Lett. 51 (1983) 415.

16/ Koch, C. C., Cavin, 0. B., McKamey, C. G., and Scarbrough, J. 0., App1. Phys. Lett. 43 (1983) 1017.

17/ Tsuei, C. C., Johnson, W. L., Laibowitz, R. B., and Viggiano, J. M., Solid State Comm. 24 (1977) 615.

/8/ Thomas, G., Mori, H., Fujita, H., and Sinclair, R., Scripta Met. 16 (1982)589. 